\title{
Perlakuan Pascapanen Buah Kesemek Reundeu (Diosphyros kaki L.) Menggunakan Gas Karbon Dioksida
}

\section{Postharvest Treatment of Reundeu Persimmon (Diosphyros kaki L.) Using Carbon Dioxide Gas}

\author{
Reski Febyanti Rauf ${ }^{1}$, Y. Aris Purwanto ${ }^{1 *}$, Sobir $^{2}$ \\ 'Program Studi Teknologi Pascapanen, Sekolah Pascasarjana, \\ Institut Pertanian Bogor Kampus IPB Darmaga, Bogor 16680 \\ ${ }^{2}$ Departemen Agronomi dan Hortikultura, Faperta IPB \\ Jl. Meranti Kampus IPB Darmaga \\ *Penulis untuk koresponden. email: arispurwanto@gmail.com
}

Diterima 11 November 2016/Disetujui 9 Januari 2017

\begin{abstract}
Postharvest treatment for removing astringency on Reundeu persimmon by traditional way, make the appearance is not attractive visually for commercial purpose. One of the alternative treatment that potentially to be applied is the high concentration of $\mathrm{CO}_{2}$ gas from dry ice. Application of deastringency treatment aimed to analyze the effectiveness of CO gas for reducing tannin content on Reundeu persimmon. Fruits were put into closed jar with dry ice at dose 10, 20, and 30 $g$ and control at ambient temperature. Treatments set for 24, 48, and 72 hours. Measurement of initial concentration of $\mathrm{CO}_{2}$ gas in the jar was carried out after dry ice sublimed. Final concentration of $\mathrm{CO}_{2}$ was measured at the end of treatment and accompanied with analyze of tannin content. The result showed that high concentration of $\mathrm{CO}_{2}$ gas $(>80 \%)$ can reduce tannin on Reundeu persimmon effectively. Based on minimum human perception, the treatment of $\mathrm{CO}_{2}$ gas as deastringency can be applied at three maturity levels, i.e. $10 \mathrm{~g}$ doses at 24 hours for green stage (0.097\%), $10 \mathrm{~g}$ doses at 48 hours for greenmature stage $(0.054 \%)$ and $10 \mathrm{~g}$ doses at 72 hours for orange-ripe stage (0.02\%). This result can be use as a reference for distribution handling of persimmon fruit to fulfill the consumers and markets demands.
\end{abstract}

Keywords: carbon dioxide gas, deastringency treatment, dry ice, persimmon, tannin.

\section{ABSTRAK}

Perlakuan pascapanen untuk menghilangkan rasa sepat buah kesemek Reundeu secara tradisional, berdampak pada penampakan visual buah yang kurang menarik secara komersial. Salah satu alternatif perlakuan yang berpotensi untuk diterapkan adalah penggunaan gas $\mathrm{CO}_{2}$ konsentrasi tinggi yang bersumber dari dry ice. Penelitian ini bertujuan untuk menganalisis efektifitas penggunaan gas $\mathrm{CO}_{2}$ konsentrasi tinggi sebagai deastringency treatment untuk menurunkan kadar tanin buah kesemek Reundeu. Buah kesemek dimasukkan ke dalam stoples tertutup dengan perlakuan dry ice pada dosis 10, 20, dan $30 \mathrm{~g}$ serta kontrol pada suhu ruang. Lamanya waktu perlakuan adalah 24, 48, dan 72 jam. Pengukuran konsentrasi gas $\mathrm{CO}_{2}$ awal dilakukan setelah dry ice dalam stoples bersublimasi. Selanjutnya dilakukan pengukuran konsentrasi CO akhir dan disertai pengukuran kadar tanin secara destruktif. Hasil penelitian menunjukkan penggunaan gas $\mathrm{CO}_{2} \mathrm{konsentrasi}^{2}$ tinggi (> 80\%) secara efektif dapat menurunkan kadar tanin buah kesemek Reundeu. Berdasarkan acuan minimum human perception, penggunaan gas $\mathrm{CO}_{2}$ sebagai deastringency treatment dapat diterapkan pada tiga tingkat kematangan buah yaitu dosis dry ice $10 \mathrm{~g} \mathrm{~kg}^{-1}$ buah untuk buah muda dengan waktu perlakuan 24 jam (0.097\%), buah tua dengan waktu perlakuan 48 jam (0.054\%) dan buah matang dengan waktu perlakuan 72 jam (0.02\%). Hasil penelitian ini dapat dijadikan rujukan dalam penanganan buah kesemek selama proses distribusi untuk memenuhi permintaan konsumen dan pasar.

Kata Kunci: deastringency treatment, dry ice, gas karbon dioksida, kesemek, tanin.

\section{PENDAHULUAN}

Kesemek Reundeu merupakan salah satu kultivar buah kesemek tipe astringent yang dikelola secara tradisional di Kecamatan Cikajang, Kabupaten Garut. Karakteristik kultivar ini umumnya tidak berbiji, memiliki ukuran buah sedang hingga besar berbentuk persegi dan pipih serta memiliki kerutan di sekitar pangkal buah (Ishaq dan Noch, 2006; Stein et al., 2012). Kulit buah muda berwarna hijau dengan daging buah yang berwarna hijau kekuningan dan bertekstur keras, padat dan kering. Sedangkan pada buah matang berwarna kuning hingga jingga dengan daging buah yang lembut dan berserat. 
Buah subtropis ini memiliki rasa kelat atau sepat yang berasal dari kandungan tanin dalam daging buah (Ishaq dan Noch, 2006). Tanin $\left(\mathrm{C}_{14} \mathrm{H}_{20} \mathrm{O}_{9}\right)$ merupakan senyawa aktif metabolit sekunder (Mailoa et al., 2013; Furlan et al., 2010), termasuk dalam kelompok polifenol (Deaville et al., 2010) yang sukar mengkristal, mampu mengendapkan alkaloid dan gelatin serta pengkhelat logam (Malangngi et al., 2012; Zhang et al., 2011). Tanin akan larut dalam air khususnya air panas dan pelarut organik seperti methanol, etanol dan aseton (Wardani dan Leviana, 2010; Budi et al., 2012). Kandungan tanin yang tinggi menyebabkan buah akan tetap sepat meskipun telah matang di pohon (Yonemori dan Suzuki, 2008; Yin et al., 2012) sehingga buah klimakterik ini sulit untuk dikonsumsi.

Penanganan pascapanen untuk menghilangkan rasa sepat (deastringency treatment) buah kesemek dilakukan petani dengan cara perendaman buah segar ke dalam air kapur. Diperlukan 3-4 kg kapur untuk $100 \mathrm{~kg}$ buah yang dilarutkan dalam 100 liter air (3-5\% larutan kapur) selama 3-5 hari (Baswarsiati et al., 2006). Metode ini mampu menghilangkan rasa sepat daging buah kesemek, akan tetapi mempengaruhi penampakan visual buah. Pengendapan serbuk kapur di permukaan kulit buah menyebabkan buah tampak ditutupi bedak yang tebal, kulit buah menjadi kasar dan warna buah menjadi pucat sehingga berdampak pada penurunan kualitas dan harga jual buah kesemek secara komersial.

Selain dengan perendaman air kapur, metode deastringency treatment lainnya dilakukan dengan gas $\mathrm{CO}_{2}$, etanol, irradiasi, hot water treatment, dan perlakuan $\mathrm{N}_{2}$ (Bibi et al., 2007; Pitojo dan Puspita, 2011; Del Bubba et al., 2009). Perlakuan gas $\mathrm{CO}_{2}$ pada beberapa penelitian dianggap lebih efektif untuk menurunkan kadar tanin buah kesemek dibandingkan dengan perlakuan lainnya (Ahmed dan Sobieh, 2007; Yin et al., 2012; Ghidelli et al., 2013) sehingga berpotensi untuk diterapkan pada kultivar kesemek yang ada di Indonesia. Efektifitas penggunaan gas $\mathrm{CO}_{2}$ konsentrasi tinggi yang bersumber dari dry ice didasarkan pada peningkatan metabolisme buah yang memicu insolubilitas molekul tanin terkondensasi terhadap asetaldehid yang dihasilkan selama respirasi (Novillo et al., 2014). Penerapan deastringency treatment ini bertujuan untuk menganalisis efektivitas penggunaan gas $\mathrm{CO}_{2}$ konsentrasi tinggi dalam menurunkan kadar tanin buah kesemek Reundeu.

\section{BAHAN DAN METODE}

Buah kesemek kultivar Reundeu berasal dari kebun petani di Kampung Areng, Desa Cigedug, Kecamatan Cikajang, Kabupaten Garut, Jawa Barat. Kesemek dengan umur 6-7 bulan setelah pembungaan dikelompokkan berdasarkan warna yang mengindikasikan tingkat kematangannya yaitu buah muda (hijau dominan), buah tua (hijau kekuningan), dan buah matang (kuning dominan sampai jingga).

Perlakuan deastringency treatment dilakukan dengan memasukkan satu $\mathrm{kg}$ buah ke dalam stoples dan menambahkan dry ice sebanyak 10, 20, $30 \mathrm{~g}$, dan kontrol (tanpa dry ice). Persentase konsentrasi gas $\mathrm{CO}_{2}$ awal diukur menggunakan Portable Carbondioxide Tester Type XP-3140 setelah dry ice bersublimasi. Proses deastringency treatment dilakukan dalam kondisi stoples tertutup dengan sirkulasi udara yang terbatas, pada suhu ruang selama 24, 48, dan 72 jam. Setelah deastringency treatment selesai, konsentrasi gas $\mathrm{CO}_{2}$ diukur kembali disertai dengan pengukuran kadar tanin secara destruktif.

Kadar tanin diukur dengan metode Lowenthal-Procter menggunakan pelarut etanol 96\%. Filtrat hasil pengenceran ekstrak buah kesemek ditambahkan larutan indigocarmin sebanyak $25 \mathrm{ml}$ dan dititrasi dengan larutan KMnO4 0.1 N. Volume titrasi dinyatakan sebagai A ml. Penetapan larutan blanko dinyatakan sebagai B ml. Kadar tanin dihitung dengan rumus sebagai berikut: (Alwala et al., 2014)

Kadar Tanin $=\frac{10(\mathrm{~A}-\mathrm{B}) \times N \times 0.004157}{\text { sampel }(\text { gram })} \times 100 \%$

Keterangan:

$\mathrm{A}=$ volume titrasi tanin $(\mathrm{ml}), \mathrm{B}=$ volume titrasi blanko $(\mathrm{ml}), \mathrm{N}=$ normalitas $\mathrm{KMnO}_{4}$ standar $(\mathrm{N}), 10=$ faktor pengenceran, $1 \mathrm{ml} \mathrm{KMnO}{ }_{4} 0.1 \mathrm{~N}=$ setara dengan 0.004157 gram tanin.

\section{HASIL DAN PEMBAHASAN}

\section{Konsentrasi Gas $\mathrm{CO}_{2}$}

Identifikasi konsentrasi gas $\mathrm{CO}_{2}$ selama proses deastringency treatment pada buah kesemek Reundeu merepresentasikan kondisi buah secara fisikokimia yang ditandai dengan peningkatan metabolisme buah. Hasil pengukuran menunjukkan adanya perubahan konsentrasi gas $\mathrm{CO}_{2}$ pada kondisi awal dan akhir perlakuan, serta adanya peningkatan jumlah konsentrasi gas $\mathrm{CO}_{2}$ pada buah kesemek dalam stoples tanpa penambahan dry ice (kontrol).

Berdasarkan Gambar 1, penambahan dry ice pada proses deastringency treatment menunjukkan adanya peningkatan konsentrasi gas $\mathrm{CO}_{2}$ pada awal pengukuran dengan rata-rata persentase di atas $80 \%$. Penambahan dry ice memicu peningkatan metabolisme buah kesemek pada kondisi sirkulasi udara yang terbatas dalam stoples. Peningkatan konsentrasi gas $\mathrm{CO}_{2}$ yang tinggi menurut Ngili (2009) menyebabkan proses sintesis asetildehid meningkat cepat. Pembentukan asetildehid dilakukan dengan bantuan enzim piruvat dekarboksilase yang gmengkatalisis konversi piruvat menjadi asetildehid. Akumulasi asetildehid yang tinggi menyebabkan proantosianidin bertransformasi (Chung et al., 2014; Salvador et al., 2008), tanin terlarut yang terdapat dalam sel-sel tanin atau yang memenuhi ruang antar sel mengalami koagulasi (Yamada et al., 2002; Woolf dan Ben-Arie, 2011). Koagulasi terjadi akibat proses polimerisasi tanin terlarut yang membentuk polimer tanin tak terlarut (Öz et al., 2005; Salvador et al., 2008; Ahmed dan Sobieh, 2007). Terbentuknya tanin tidak terlarut yang dominan mengindikasikan penurunan kesepatan pada buah kesemek. Dampak penambahan dry ice selama proses deastringency treatment selain memicu penghilangan kesepatan, proses tersebut juga menekan laju respirasi buah 
sehingga persentase konsentrasi gas $\mathrm{CO}_{2}$ dalam stoples menjadi fluktuatif, cenderung mengalami penurunan, ditunjukkan pada grafik konsentrasi akhir gas $\mathrm{CO}_{2}$ (Gambar 1).

Konsentrasi gas $\mathrm{CO}_{2}$ khususnya pada buah kesemek tanpa penambahan dry ice (kontrol), pada pengukuran awal menunjukkan persentase rata-rata di bawah $1 \%$. Selanjutnya, pada pengukuran akhir mengalami peningkatan mencapai rata-rata di atas 15\% (Gambar 1). Peningkatan konsentrasi gas $\mathrm{CO}_{2}$ pada perlakuan kontrol yang signifikan mengindikasikan tingginya laju respirasi buah kesemek selama proses deastringency treatment, akan tetapi peningkatan tersebut tidak mampu memicu sintesis asetildehid yang cepat untuk menghilangkan kesepatan. Hal ini menunjukkan bahwa dibutuhkan persentase konsentrasi gas $\mathrm{CO}_{2}$ tertentu untuk menurunkan kadar tanin buah kesemek. Penambahan dry ice dengan hasil pengukuran konsentrasi gas $\mathrm{CO}_{2} 80 \%$ efektif menurunkan kadar tanin pada buah kesemek Reundeu selama proses deastringency treatment.

\section{Kadar Tanin}

Persentase kadar tanin buah kesemek Reundeu menunjukkan adanya perbedaan yang signifikan antara buah dengan perlakuan gas $\mathrm{CO}_{2}$ dan kontrol. Perlakuan kontrol pada tiga tingkat kematangan buah merepresentasikan rata-rata persentase kandungan tanin yang lebih tinggi dibandingkan buah dengan perlakuan gas $\mathrm{CO}_{2}$ (Gambar 2). Hal tersebut membuktikan bahwa buah kesemek tipe astringent akan tetap mengandung kadar tanin yang tinggi yang mengindikasikan rasa sepat pada buah jika tidak dilakukan penanganan deastringency treatment (Ishaq dan

Konsentrasi $\mathrm{CO} 2$ awal

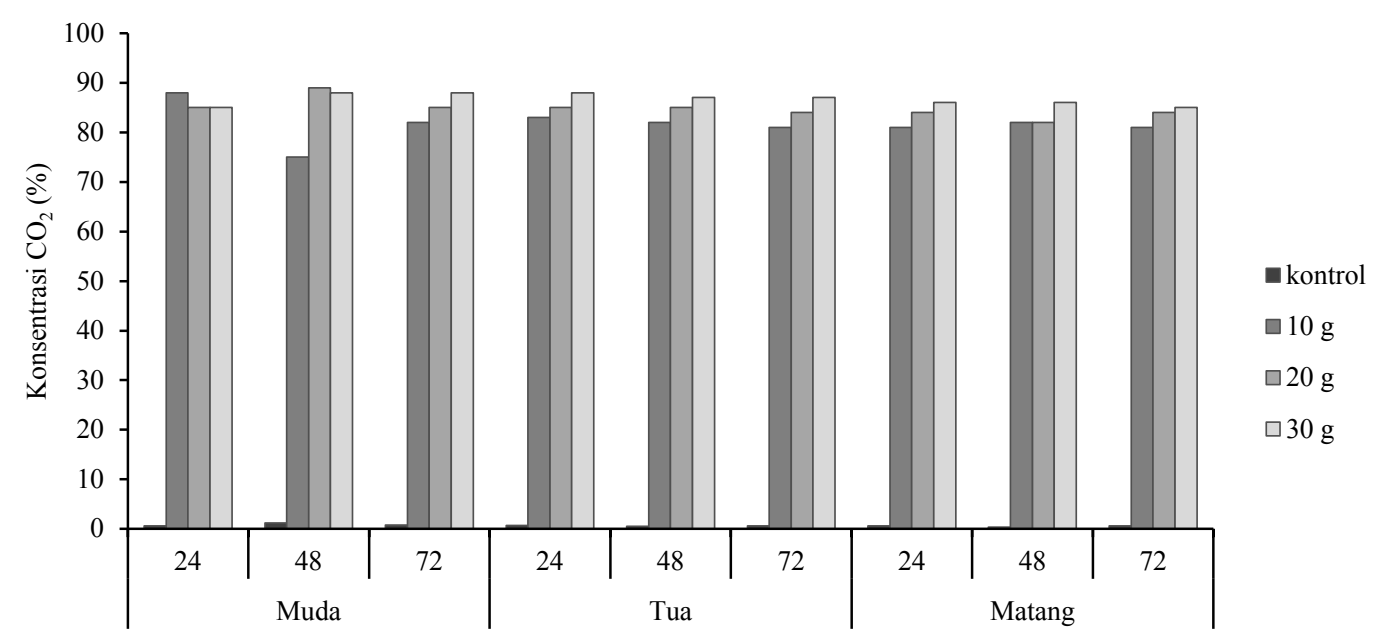

Waktu treatment (jam) dan tingkat kematangan

Konsentrasi CO2 akhir

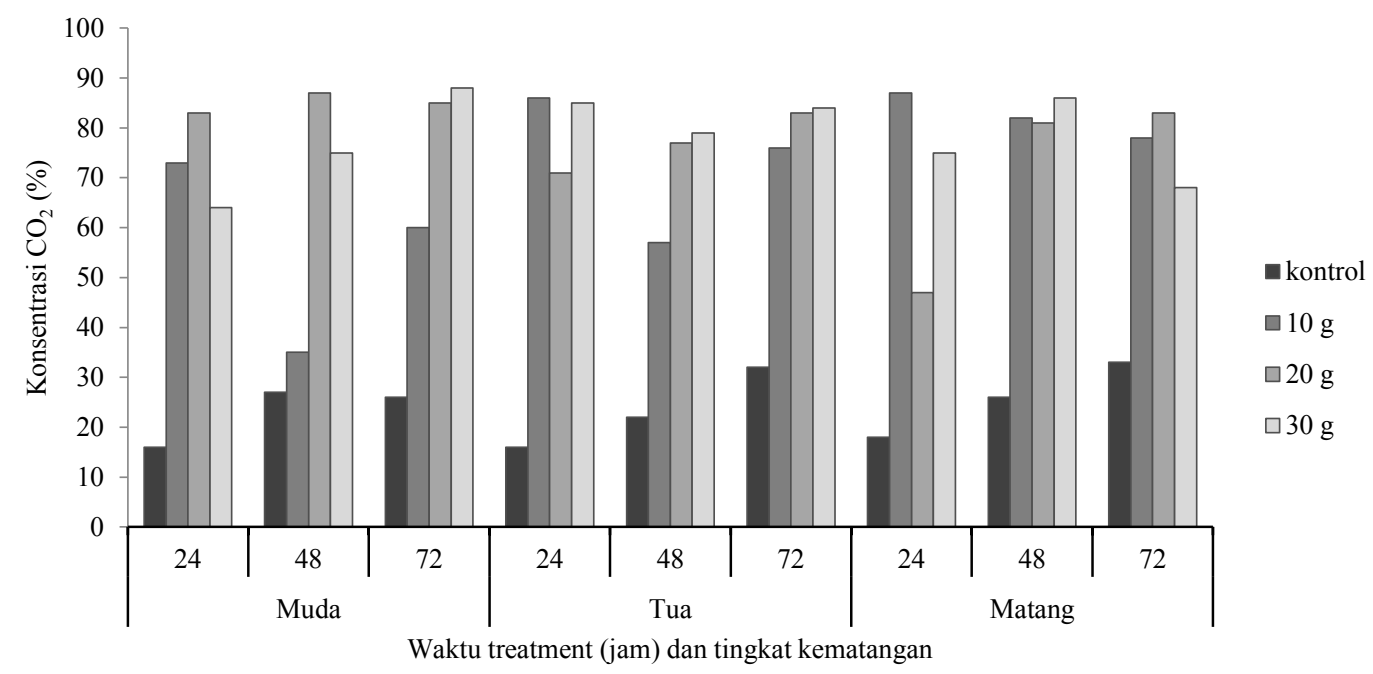

Gambar 1. Konsentrasi gas $\mathrm{CO}_{2}$ pada tiga tingkat kematangan buah dengan kombinasi dosis (g) dan waktu treatment (jam) 
Noch, 2006; Yin et al., 2012). Perlakuan dry ice untuk tiga tingkat kematangan buah tidak menunjukkan perbedaan nyata pada taraf dosis 10, 20, dan 30 g. Persentase konsentrasi gas $\mathrm{CO}_{2}$ yang dihasilkan untuk setiap taraf $d r y$ ice ratarata berkisar pada nilai persentasi yang sama, sehingga penggunaan dry ice $10 \mathrm{~g}$ telah mampu menurunkan kadar tanin buah kesemek.

Kombinasi faktor tingkat kematangan dan lamanya waktu deastringency treatment mempengaruhi besarnya penurunan kadar tanin buah kesemek. Pada buah muda dan tua, waktu perlakuan selama 72 jam menunjukkan adanya penurunan persentase kadar tanin yang signifikan. Hasil ini sesuai dengan Chia et al. (2009) yang menyebutkan bahwa deastringency treatment dengan dry ice selama 72 jam mampu menurunkan kadar tanin buah kesemek kultivar 'Maru'. Meskipun perlakuan 72 jam mampu menurunkan kadar tanin buah, akan tetapi resiko penurunan kualitas buah akan meningkat akibat waktu perlakuan yang lebih lama khususnya pada buah kesemek matang. Dampak deastringency treatment pada buah matang adalah terjadinya penurunan tingkat kekerasan dan kondisi buah yang lebih cepat rusak. Oleh karena itu, lamanya waktu perlakuan perlu dipertimbangkan untuk masing-masing tingkat kematangan buah untuk mempertahankan kualitas secara komersial termasuk pertimbangan distribusi buah.

Penggunaan acuan minimum human perception dalam menentukan kadar tanin buah kesemek secara komersial menjadi standar yang dapat diterapkan. Nilai acuan yang digunakan adalah kurang dari $0.1 \%$ tanin terlarut atau 1.0 $\mathrm{mg} \mathrm{g}^{-1}$ daging buah (Salvador et al., 2008; Yamada et al., 2002). Menurut Karakasova et al. (2013) tanin teridentifikasi dalam keadaan terlarut pada 0-4\% tergantung kultivar buah. Ahmed dan Sobieh (2007) menambahkan bahwa buah yang mengandung $0.2 \%$ tanin terlarut masih memiliki rasa sepat dan dapat dikonsumsi ketika kadar tanin menurun kurang dari $0.1 \%$ hingga buah hampir menjadi non-astringent. Penggunaan acuan minimum human perception memberikan pilihan untuk perlakuan deastringency treatment dengan kondisi yang sesuai pada setiap tingkat kematangan buah kesemek Reundeu. Berdasarkan acuan tersebut, persentase penurunan kadar tanin dapat dicapai pada penggunaan dosis dry ice $10 \mathrm{~g}$ untuk tiga tingkat kematangan buah dengan waktu perlakuan selama 24 jam pada buah muda, 48 jam pada buah tua dan 72 jam pada buah matang. Perlakuan tersebut secara berurutan menghasilkan buah kesemek dengan kandungan tanin sebesar $0.097 \%$, 0.054\%, dan $0.02 \%$.

Buah kesemek muda dan tua menunjukkan ratarata persentase penurunan kadar tanin yang lebih besar dibandingkan dengan buah matang (Gambar 2). Buah muda dan tua mengindikasikan adanya kandungan pati yang tinggi sehingga produksi glukosa meningkat untuk sintesis asetildehid. Akumulasi asetildehid yang tinggi akan lebih cepat memicu polimerisasi tanin terlarut menjadi tanin tidak terlarut (Yakushiji dan Nakatsuka, 2007). Sedangkan pada buah matang, proses metabolisme meningkat, seperti pembelahan sel yang aktif dan meningkatnya kerja enzim untuk menghidrolisis cadangan makanan sehingga menghasilkan zat terlarut seperti tanin yang lebih banyak selama periode pematangan (Yin et al., 2012). Selain itu, kandungan pati yang semakin rendah menyebabkan produksi glukosa untuk sintesis asetildehid menjadi berkurang. Akumulasi asetildehid yang rendah menghambat proses transformasi tanin.
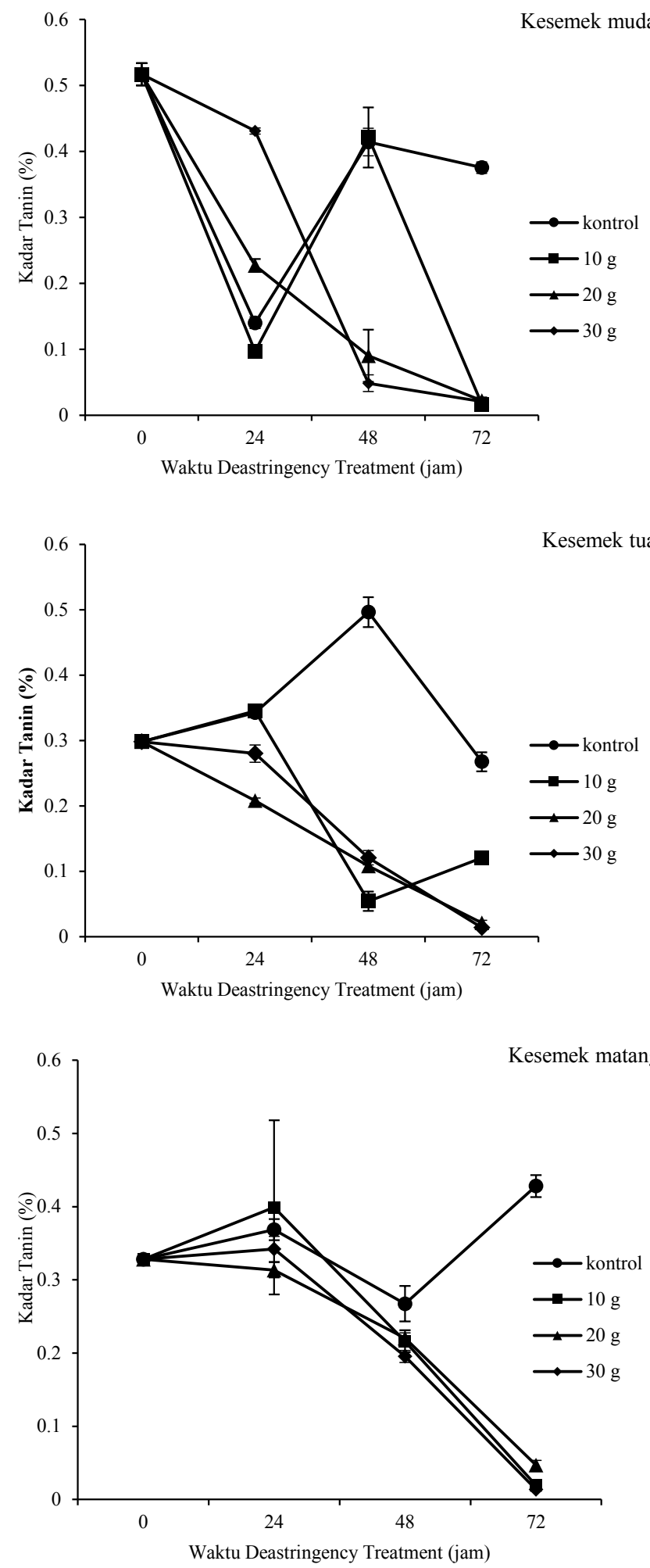

Gambar 2. Kadar tanin untuk tiga tingkat kematangan buah dengan kombinasi dosis (g) dan waktu treatment (jam) 


\section{KESIMPULAN}

Peningkatan laju respirasi pada buah kesemek Reundeu selama proses deastringency treatment dipengaruhi oleh reaksi metabolisme buah yang menunjukkan ciri buah kesemek sebagai buah tipe klimakterik. Konsentrasi gas $\mathrm{CO}_{2}$ yang tinggi $(>80 \%)$ secara efektif mampu menurunkan kadar tanin buah kesemek Reundeu selama proses deastringency treatment untuk tiga tingkat kematangan buah. Penggunaan gas $\mathrm{CO}_{2}$ sebagai deastringency treatment berdasarkan acuan minimum human perception, dapat diterapkan dengan dosis $10 \mathrm{~g} \mathrm{~kg}^{-1}$ buah pada tiga tingkat kematangan buah, yaitu buah muda pada waktu perlakuan 24 jam (0.097\%), buah tua dengan waktu perlakuan 48 jam $(0.054 \%)$ dan buah matang pada waktu perlakuan 72 jam $(0.02 \%)$. Perlakuan deastringency treatment dengan gas $\mathrm{CO}_{2}$ konsentrasi tinggi yang diterapkan selain mampu menghilangkan rasa sepat, juga dapat mempertahankan kualitas buah secara komersial khususnya dalam penanganan distribusi buah yang tepat.

\section{DAFTAR PUSTAKA}

Ahmed, D.M., M.E. Sobieh. 2007. Removing astringency of costata persimmon fruits by carbon dioxide and nitrogen-enriched atmospheres. American-Eurasian J. Agr. Environ. Sci. 2(6):731-740.

Alwala, J.O., F.N. Kiema, W. Wanzala. 2014. Determination of tannin concentration in african indigenous vegetables, grains and cassava roots from Emuhaya Distric, Western Kenya. American J. Nutr. Food Sci. $1(1): 1-8$.

Baswarsiati, Suhardi, D. Rahmawati. 2006. Potensi dan wilayah pengembangan kesemek junggo. Buletin Plasma Nutfah. 12(2):56-61.

Bibi, N., A.B. Khattak, Z. Mehmood. 2007. Quality improvement and shelf life extension of persimmon fruit (Diospyros kaki). J. Food Eng. 79:1359-1363.

Budi, S.W., A. Sukendro, L. Karlinasari. 2012. Penggunaan pot berbahan dasar organik untuk pembibitan Gmelina arborea Roxb. di persemaian. J. Agron. Indonesia. 40(3):239-245.

Chia, C.L., C. Hashimoto, D.O. Evans. 2009. Persimmon. Original of Hawaii Cooperative Extension Service of University of Hawaii. Manoa (HI).

Chung, H.S., H.S. Kim, Y.G. Lee, J.H. Seong. 2014. Effect of deastringency treatment of intact fruits on the quality of fresh-cut persimmons. Food Chem. 166:192-197.

Deaville, E.R., D.I. Givens, I. Mueller-Harvey. 2010. Chestnut and mimosa tannin silages: effects in sheep differ for apparent digestibility, nitrogen utilisation and losses. Anim. Feed Sci. Technol. 157:129-138.
Del Bubba, M., D.E. Giordani, L. Pippucci, A. Cincenelli, L. Checchini, P. Galvan. 2009. Changes in tannis, ascorbic acid and sugar content in astringent persimmons during on-tree growth and ripening and in response to different postharvest treatments. J. Food Composition and Analysis. 22:668-677.

Furlan, C.M., L.B. Motta, D.Y.A. Cursino dos Santos. 2010. Tannins: what do they represent in plant life? In Georgios K. Petridis (Ed). Tannins: Types, Foods Containing and Nutrition. New York (US): Nova Science. 251-264.

Ghidelli, C., C. Rojas-Argudo, M. Mateos, M.B. Pérez-Gago. 2013. Effect of antioxidants in controlling enzymatic browning of minimally processed persimmon 'Rojo Brillante'. Postharvest Biology and Technology. 86:487-493.

Ishaq, I., M. Noch. 2006. Buah kesemek: Potensi sumber daya genetik Kabupaten Garut Jawa Barat. Prosiding Lokakarya Nasional Pengelolaan dan Perlindungan Sumber Daya Genetik di Indonesia: Manfaat Ekonomi untuk Mewujudkan Ketahanan Nasional. Puslitbang Peternakan Bogor. Bogor. hlm 108-118.

Karakasova, L., F. Babanovska-Milenkovska, M. Lazov, B. Karakasov, D. Stojanova. 2013. Quality properties of solar dried persimmon (Diospyros kaki L.). J. Hyg. Eng. Des. 1:54-59.

Mailoa, M.N., M. Mahendradatta, A. Laga, N. Djide. 2013. Tannin extraxt of guava leaves (Psidium guajava L.) variation with concentration organic solvents. Int. J. Sci. Technol. Res. 2(9):106-110.

Malangngi,P.L., M.S. Sangi, J.J.E.Paedong. 2012.Penentuan kandungan tanin dan uji aktivitas antioksidan ekstrak biji buah alpukat (Persea americana Mill.). Jurnal Mipa UNSRAT Online. 1:5-10.

Ngili, Y. 2009. Biokimia, Metabolisme dan Bioenergetika. Yogyakarta (ID): Graha Ilmu.

Novillo, P., A. Salvador, T. Magalhaes, C. Besada. 2014. Deastringency treatment with $\mathrm{CO}_{2}$ induces oxidative stress in persimmon fruit. Postharvest Biol. Technol. 92:16-22.

Öz, A.T., I.S. Özelkök, B. Albayrak. 2005. Sugar and tannin changes in persimmon fruit during artificial ripening with dry ice. In F. Mencarelli, P. Tonutti (Eds). Proceeding of The Fifth International Postharvest Symposium; 2005; Acta Hortic. 682:987-992.

Pitojo, S., H.N. Puspita. 2011. Kesemek Seri Budi Daya. Ed ke-5. Yogyakarta. Kanisius. 
Salvador, A., L. Arnal, C. Besada, V. Larrea, I. Hernando, I. P'erez-Munuera. 2008. Reduced effectiveness of the treatment for removing astringency in persimmon fruit when stored at $15^{\circ} \mathrm{C}$ : Physiological and microstructural study. Postharvest Biol. Technol. 49:340-347.

Stein, L., M. Nesbitt, J. Kamas. 2012. Persimmon. Texas Fruit and Nut Production. AgriLife Extension. Texas (US).

Wardani, A.T., F. Leviana. 2010. Pengaruh cairan penyari terhadap rendemen dan kadar tanin ekstrak daun jambu biji (Psidium guajava L.). Jurnal Farmasi Indonesia. 7(2):57-61.

Woolf, A.B., R. Ben-Arie. 2011. Persimmon (Diospyros kaki L.). In E.M. Yahia (Ed). Postharvest biology and technology of tropical and subtropical fruits volume 4: mangosteen to white sapote. Cambridge (GB). Woodhead Publishing Series in Food Science, Technology and Nutrition. 209:166-193.

Yakushiji, H., A. Nakatsuka. 2007. Recent persimmon research in Japan. Japanese J. Plant Sci. 1(2):42-62.
Yamada, M., S. Taira, M. Ohtsuki, A. Sato, H. Iwanami, H. Yakushiji, R.Z. Wang, Y. Yang, G.C. Li. 2002. Varietal differences in the ease of astringency removal by carbon dioxide gas and ethanol vapor treatments among oriental astringent persimmons of Japanese and Chinese origin. Sci. Hortic. 94:63-72.

Yin, X.R., Y.N. Shi, T. Min, Z.R. Luo, Y.C. Yao, Q. Xu, I. Ferguson, K.S. Chen. 2012. Expression of ethylene response genes during persimmon fruit astringency removal. Planta. 235:895-906.

Yonemori, K., Y. Suzuki. 2008. Differences in three dimensional distribution of tannin cells in flesh tissue between astringent and non-astringent type persimmon. In E. Bellini, E. Giordani (Eds). Proceeding of The Fourth International Symposium on Persimmon; 2009 Juni 16; Firenze, Faenza, Caserta, Italy (IT): Acta Hortic. 833:119-124.

Zhang, T., G. Li, H. Mo, C. Zhi. 2011. Persimmon tannin composition and function. International Conference on Agricultural and Biosystems Engineering. Adv. Biomed. Eng. 1-2:389-392. 